\title{
Rapid and Sensitive Analytical Method for the Determination of Insulin in Liposomes by Reversed-Phase HPLC
}

\author{
Eliete de Souza Von Zuben, ${ }^{1,}$ Josimar Oliveira Eloy, ${ }^{2}$ Victor Hugo Sousa Araujo, ${ }^{1}$ \\ Maria Palmira Daflon Gremião ${ }^{1}$ and Marlus Chorilli ${ }^{1}$ \\ ${ }^{1}$ São Paulo State University (UNESP), School of Pharmaceutical Sciences, Department of Drugs and Medicines, \\ Rodovia Araraquara-Jaú, km1, 14800-903, Araraquara, São Paulo, Brazil. \\ ${ }^{2}$ Federal University of Ceará, School of Pharmacy, Dentistry and Nursing, Department of Pharmacy, Fortaleza - CE, Brazil \\ *Corresponding author: E-mail: eliete.vz@gmail.com \\ Tel.: +551633016960
}

Received: 08-20-2020

\begin{abstract}
Insulin is an important anabolic hormone that regulates the metabolism of carbohydrates, lipids and proteins. In this study, a reverse-phase liquid chromatography (RP-LC) method was successfully validated and tested for the encapsulation efficiency assay of insulin and in vitro release studies. HPLC analyses were carried out using a RP C18- Luna ${ }^{\circledR}$ Phenomenex $(4.6 \times 250 \mathrm{~mm}, 5 \mu \mathrm{m}$ particle size $)$ column maintained at room temperature, using a mobile phase constituted by a mixture of acetonitrile and $0.1 \%$ TFA aqueous solution $(60: 40, \mathrm{v} / \mathrm{v})$, in an isocratic mode with a flow rate of $1.0 \mathrm{~mL} /$ min, with ultraviolet detection at $214 \mathrm{~nm}$ and $20 \mu \mathrm{L}$ of injection volume. Method validation was performed according recognized guidelines for system suitability, specificity, linearity, precision, accuracy, LOD, LOQ and robustness. The method was shown to be linear in the range of $0.5-100 \mu \mathrm{g} / \mathrm{mL}\left(\mathrm{r}^{2}=0.9993\right)$ selective, precise, robust, accurate with LOD and LOQ values were $0.097 \mu \mathrm{g} / \mathrm{mL}$ and $0.294 \mu \mathrm{g} / \mathrm{mL}$, respectively. The developed method proved to be adequate to analyze the encapsulation efficiency and the profile of insulin release from liposomes.
\end{abstract}

Keywords: Insulin; liposome; liquid Chromatography; validation Method; in Vitro Release; encapsulation Efficiency.

\section{Introduction}

Insulin is a polypeptide with a molecular weight of $5.8 \mathrm{kDa}$, synthesized in the pancreas by $\beta$-cells of the islets of Langerhans, from a larger molecule called proinsulin. Proinsulin is enzymatically cleaved to generate insulin (which contains 51 amino acids arranged in two chains interconnected by disulfide bonds, $\alpha$ being 21 amino acids and $\beta$ with 30 amino acids) and the $C$ peptide. The insulin and peptide $\mathrm{C}$ are secreted in equimolar amounts when beta-pancreatic cells are stimulated, however, peptide $\mathrm{C}$ does not play any physiological function. ${ }^{1}$

Insulin is an important anabolic hormone that regulates the metabolism of carbohydrates, lipids and proteins. The uptake of glucose by organs such as liver, skeletal muscle and adipose tissue is performed by the action of insulin. In the absence of insulin, the uptake of glucose by said organs and tissues is affected leading to hyperglycemia.
Other insulin functions are related to ion transport, cell proliferation and differentiation, and nitric oxide synthesis. $^{2}$

Recent research has triggered the development of new insulin delivery systems that allow the use of alternative routes to parenteral (subcutaneous injection). The injection of insulin preparations sometimes results in subcutaneous adipose tissue hypertrophy, if it will be administrating repeatedly in the same place and the other side effect is the risk of hypoglycemia when treatment becomes continuous. ${ }^{3}$

Liposomes in 1995 were the first nanoscale release system to be used for clinical use. Since then, work based on this type of release systems has grown considerably and brought enormous development with significant clinical implications. ${ }^{4}$ Several researchers used nanostructured systems such as liposomes for encapsulation and release of insulin. ${ }^{5-7}$ 
Over the recent years, some methods for the quantification of insulin in the formulation, bulk and nanostructured systems by HPLC have appeared in the literature. ${ }^{8-12}$

Thus, the purpose of the present paper was to develop and validate a simple, sensitive and fast reversed-phase HPLC method for the measurement of insulin in liposomes. This method was validated following the ICH and FDA guidelines together Brazilian National Health Surveillance Agency (ANVISA) resolution, assuring the therapeutic efficacy and contributing to the improvement of the quality control. ${ }^{13-15}$

\section{Experimental}

\section{1. Chemical and Reagents}

The human insulin solution Novolin $\mathrm{R}^{\circledR}(100 \mathrm{IU} / \mathrm{mL}$, Lot GS63F52) was purchased from Novo Nordisk, Kalundborg, Denmark. Soybean phosphatidylcholine (Lipoid S100; PC > 96\%) was obtained from Lipoid GmbH, Germany. Cholesterol $(\mathrm{CH})$ was purchased from Sigma-Aldrich, USA (purity $\geq 99 \%$ ). Chloroform obtained from Merck, USA. Acetonitrile and methanol were acquired from J.T. Baker ${ }^{\circledR}$, USA (HPLC grade) and trifluoroacetic acid (TFA) were purchased from Sigma-Aldrich, USA. Amicon ${ }^{\circledR}-100 \mathrm{kDa}$ ultrafiltration filter was purchased from Millipore. Water was prepared by Milli-Q reverse osmosis (Millipore, USA). All other reagents were commercially available and of analytical grade. Phosphate buffered saline (PBS) is made of $\mathrm{NaCl} 137 \mathrm{mmol} / \mathrm{L}, \mathrm{KCl} 2.6 \mathrm{mmol} / \mathrm{L}$, $\mathrm{Na}_{2} \mathrm{HPO}_{4} \cdot 12 \mathrm{H} 2 \mathrm{O} 6.4 \mathrm{mmol} / \mathrm{L}$ and $\mathrm{NaH}_{2} \mathrm{PO}_{4} 1.4 \mathrm{mmol} / \mathrm{L}$, $\mathrm{pH}$ 7.4.

\section{2. Preparation of Reference Standard Solution}

The stock solution of $700 \mu \mathrm{g} / \mathrm{mL}$ was prepared by direct dilution of $2 \mathrm{~mL}$ of human insulin Novolin $R^{\circledR}(100$ $\mathrm{IU} / \mathrm{mL}$ ) in a $10 \mathrm{~mL}$ volumetric flask. The volume was completed with phosphate buffer solution (PBS), pH 7.4. From the stock solution, calibration curves for seven human insulin standard solutions were prepared at concentrations of $0,5,1,5,20,40,50$ and $100 \mu \mathrm{g} / \mathrm{mL}$ in phosphate buffer solution (PBS) $\mathrm{pH}$ 7.4. All solutions were filtered through a $0.45 \mu \mathrm{m}$ PVDF membrane filter (Millipore) prior to injection and assayed by HPLC.

\section{3. HPLC System and Chromatographic Conditions}

The RP-LC method was performed on an Agilent Technologies LC system, model 1200 DAD/UV-visible detector and was carried out the adaptation (change in the proportion of the mobile phase) of the method described by Sarmento and collaborators. The detector was set to 214 $\mathrm{nm}$ and peak areas were integrated automatically using a computer system with ChemStation data acquiring software. RP C18- Luna ${ }^{\circledR}$ Phenomenex $(4.6 \times 250 \mathrm{~mm}, 5 \mu \mathrm{m}$ particle size) column was employed for chromatographic separation with a mobile phase constituted by a mixture of acetonitrile and $0.1 \%$ TFA aqueous solution $(60: 40, \mathrm{v} / \mathrm{v})$, in an isocratic mode with a flow rate of $1.0 \mathrm{~mL} / \mathrm{min}$. The HPLC system was performed at room temperature $(25 \pm$ $\left.1{ }^{\circ} \mathrm{C}\right)$. The injection volume was $20 \mu \mathrm{L}$ for both the reference substance solution and the sample solution. Prior to use, acetonitrile and $0.1 \%$ TFA aqueous solution prepared with deionized water (Milli- ${ }^{\circledR}$ ), filtered with a $0.45 \mu \mathrm{m}$ filter and degassed for $30 \mathrm{~min}$. All samples were filtered through a $0.45 \mu \mathrm{m}$ PVDF membrane filter from Millipore, USA.

\section{4. Validation of HPLC Method}

Method validation was performed in agreement with $\mathrm{ICH}$ and FDA guidelines together Brazilian National Health Surveillance Agency (ANVISA) resolution for system suitability, specificity, linearity, precision, accuracy, limit of detection (LOD), limit of quantitation (LOQ) and robustness. ${ }^{13-15}$

\section{4. 1. System Suitability Test}

In order to assure the performance and reproducibility of the chromatographic system before and during the analysis, six injections of insulin standard solution were carried out at a concentration of $50 \mu \mathrm{g} / \mathrm{mL}$. The parameters measured were retention time, peak area, peak symmetry, tailing factor and number of theoretical plates. ${ }^{14}$

\section{4. 2. Selectivity}

Chromatograms of mobile-phase components, samples of phosphate buffer solution (PBS), $\mathrm{pH} 7.4$ and samples of blank liposomes prepared without adding insulin were obtained to evaluate the selectivity of the method. All samples were filtered through a $0.45 \mu \mathrm{m}$ PVDF membrane filter (Millipore) and injected in triplicate.

\section{4. 3. Linearity}

The linearity was evaluated by the construction of three analytical curves, determined by the analysis of seven levels of concentration in three different days. Standard solutions at the concentrations of $0.5,1,5,20,40,50$ and $100 \mu \mathrm{g} / \mathrm{mL}$ were prepared from the insulin stock solution $(700 \mu \mathrm{g} / \mathrm{mL})$ using phosphate buffer solution (PBS, $\mathrm{pH}$ 7.4 ) as the diluent. For each described concentration, three injections were carried out previously filtered through a $0.45 \mu \mathrm{m}$ PVDF membrane filter (Millipore). Linearity was determined by the calculation of a linear regression using the least-squares method and the statistical analysis was performed by analysis of variance (ANOVA). 


\section{4. 4. Precision}

The precision of the analytical method was evaluated by determination of the repeatability and the intermediate precision. The repeatability (intra-day) was determined by injection of six independent preparations of insulin standard solutions at a concentration of $50 \mu \mathrm{g} / \mathrm{mL}$, on the same day and under the same experimental conditions. The intermediate precision (inter-day) was tested using two different analysts on different days, with the same LC instrument, in the same laboratory. The \% RSD of assays was calculated.

\section{4. 5. Accuracy}

The accuracy was assessed by standard addition technique where liposomes were spiked with known quantities of insulin standard solution, at three different levels (lower, medium and upper concentration) corresponding to 5,20 and $50 \mu \mathrm{g} / \mathrm{mL}$. The samples were prepared in triplicate and the recovery percentage was determined as the percentage of the drug recovered from the sample and expressed as a relative percentage (\%).

\section{4. 6. Limit of Detection (LOD) and Quantitation (LOQ)}

The LOD and LOQ were calculated, using the mean values of three independent analytical curves, determined by a linear regression model, based on the standard deviation of the response and on the slope of the calibration curve, according to following equations 1 and 2 respectively:

$$
\begin{aligned}
& \mathrm{LOD}=3.3(\sigma / \mathrm{S}) \\
& \mathrm{LOQ}=10(\sigma / \mathrm{S})
\end{aligned}
$$

where " $\sigma$ " represents the standard deviation of y-inter- $\mu \mathrm{m}$ PVDF membrane filter (Millipore) and injected in triplicate.

\section{5. Application of the Method}

\section{5. 1. Preparation of Blank Liposome and Insulin-loaded Liposome}

Blank liposomes and insulin-loaded liposomes were prepared by the hydration of the thin lipid film as previously described by Bangham et al. ${ }^{16}$ Briefly, a phospholipid mixture of $100 \mathrm{mg}$, including soybean phosphatidylcholine (PC) and cholesterol $(\mathrm{CH})$ was weighed (weight ratios of 5:3) into a round-bottom flask and dissolved in a chloroform / methanol mixture $(1: 2 \mathrm{v} / \mathrm{v})$, evaporated using a rotary evaporator at $40{ }^{\circ} \mathrm{C}$ for 30 minutes. Then, to prepare blank liposomes, the lipid film formed was hydrated with 10 $\mathrm{mL}$ of phosphate buffer (PBS, $\mathrm{pH} 7.4$ ) for $30 \mathrm{~min}$ at $40^{\circ} \mathrm{C} /$ $100 \mathrm{rpm}$, obtaining the liposomal suspension. To prepare the liposome loaded with insulin, hydration was performed with $10 \mathrm{~mL}$ of phosphate buffer (PBS, pH 7.4), containing 4 $\mathrm{mL}$ of insulin solution, equivalent to $1400 \mu \mathrm{g} / \mathrm{mL}$, obtaining the liposomal suspension. ${ }^{17}$

\section{5. 2. Insulin Encapsulation Efficiency (EE)}

For the determination of the encapsulation efficiency of insulin, an indirect method was used by determining the free amount of insulin, non-encapsulated. Briefly, $1 \mathrm{~mL}$ of the encapsulated insulin from the liposome was separated from the free insulin by ultracentrifugation of liposomes using Amicon ${ }^{\circledR}-100 \mathrm{kDa}$ ultrafiltration filter at $13.000 \mathrm{rpm}$ for $12 \mathrm{~min}$. After centrifugation, $250 \mu \mathrm{l}$ of the filtrate was diluted to $2 \mathrm{~mL}$ with phosphate buffer (PBS, $\mathrm{pH}$ 7.4) and measured by an HPLC using the validated analytical method described previously. All experiments were performed in triplicate. The $\mathrm{EE} \%$ of insulin was calculated according to equation 3 below. ${ }^{18-19}$

$\mathrm{EE} \%$ of insulin $=\left(\begin{array}{c}\text { Total amount of insulin }(\mu \mathrm{g})-\text { Free amount of insulin } \\ \text { Total amount of insulin }(\mu \mathrm{g})\end{array}\right) \times 100$

cept of regression line and "S" denotes the slope of regression line.

\section{4. 7. Robustness}

Robustness was assessed by varying four parameters independently. The flow rate of the mobile phase $(0.9 \mathrm{~mL} /$ min and $1.1 \mathrm{~mL} / \mathrm{min})$, wavelength $(213 \mathrm{~nm}$ and $215 \mathrm{~nm})$, column temperature $\left(24^{\circ} \mathrm{C}\right.$ and $\left.26^{\circ} \mathrm{C}\right)$ and the ratio of mobile phase constituted by a mixture of acetonitrile and $0.1 \%$ TFA aqueous solution (61:39 and 59:41). For this study, the analysis was performed using a concentration of $50 \mu \mathrm{g} / \mathrm{mL}$ and all samples were filtered through a 0.45

\section{5. 3. In Vitro Release of Insulin Solution and Insulin from Liposomes}

In vitro insulin release profile from solution and liposome was investigated using Franz diffusion cells (Hanson MicroettePlus ${ }^{\circledR}$ equipment, Chatsworth, CA, USA). The cells were filled with $7.0 \mathrm{~mL}$ of receptor solution composed by phosphate buffer solution (PBS, $\mathrm{pH}$ 7.4), stirred at $300 \mathrm{rpm}$ and heated at $32{ }^{\circ} \mathrm{C} \pm 0.5^{\circ} \mathrm{C}$ to simulate nasal temperature. ${ }^{20,21}$ Aliquots of samples (2,8 $\mathrm{mL}$ ) were withdrawn automatically at predetermined intervals $(0.08,0.5,1,2,4,8,12,16$ and $24 \mathrm{~h})$ and sample volumes were replenished with fresh receptor solution. 
The amount of insulin released from solution and the liposomes was quantified by the HPLC method as described in the section 2.3.

\section{Results and Discussion}

A reversed-phase HPLC method for the determination of insulin in liposomes has been developed. The analytical parameters of selectivity, linearity, precision, accuracy, $\mathrm{LOD}, \mathrm{LOQ}$, and robustness were evaluated to validate the method, according to recognized guidelines (FDA, ICH e Anvisa). During preliminary studies, some chromatographic conditions were tested. ${ }^{5,9,12}$ It was decided to carry out the adaptation of a method previously reported. ${ }^{9}$ However, the proportion of the mobile phase was modified using the isocratic mode as a choice and this modification provided a reduced run time, best chromatographic peak resolution and good symmetry. Moreover, no degradation peak was observed.

\section{1. Validation of HPLC Method}

Validation of the method was performed according to ICH and FDA guidelines together Brazilian National Health Surveillance Agency (ANVISA) resolution. ${ }^{13-15}$ Table 1 represents the HPLC conditions for the determination of insulin in liposome.

The system suitability is used to check if the chromatographic system is suitable for the intended analysis that will be executed. ${ }^{22}$ Figure 1 shows two peaks (between 1.6 minutes and 3 minutes) from the mobile phase and the phosphate buffer (PBS, pH 7.4) and a representative peak
Table 1. HPLC conditions for determination of insulin in liposomes.

\begin{tabular}{cc}
\hline System & Parameters \\
\hline HPLC equipment & HPLC AGILENT, model 1200 \\
Mobile phase & Acetonitrile $: 0.1 \%$ TFA \\
& aqueous solution $(60: 40, \mathrm{v} / \mathrm{v})$ \\
Column & RP C18- Luna ${ }^{\circledR}$ Phenomenex \\
Wavelength & $(4.6 \times 250 \mathrm{~mm}, 5 \mu \mathrm{m}$ particle size $)$ \\
Flow rate & $214 \mathrm{~nm}$ \\
Volume of injection & $1.0 \mathrm{~mL} / \mathrm{min}$ \\
Temperature & $20 \mu \mathrm{L}$ \\
Retention time & $25 \pm 1{ }^{\circ} \mathrm{C}$ \\
\hline
\end{tabular}

of insulin (4.5 minutes). Besides, no peak of possible degradation products was observed in the chromatograms, as verified in the selectivity tests. The following results were obtained: tailing factor of 1.41 , peak asymmetry of 0.64 and theoretical plates of 5089. All parameters found are in agreement with the FDA and ICH guidelines.13-14 The average retention time was 4.5 minutes and the \% RSD of peak area was $0.22 \%$.

In this selectivity parameter mobile-phase components, samples of phosphate buffer solution (PBS), $\mathrm{pH} 7.4$ and the samples of blank liposomes composed by soybean phosphatidylcholine and cholesterol prepared without adding insulin were previously diluted with acetonitrile, sonicated for 10 minutes, filtered $(0.45 \mu \mathrm{m})$ and then analyzed by HPLC. All the samples were injected separately and the assay was performed in triplicate and the peaks obtained showed that there was no interference of the samples injected at the peak of insulin.

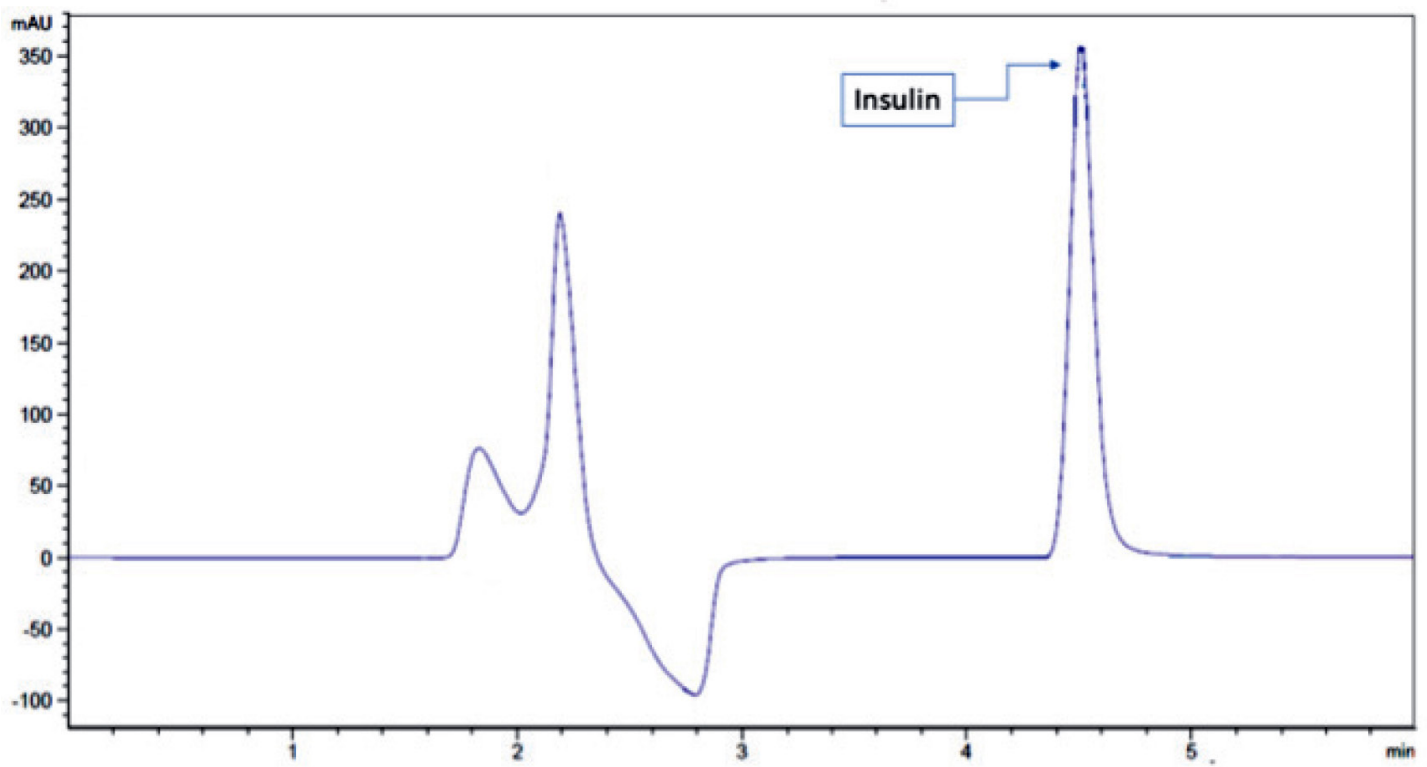

Figure 1. Representative chromatogram of insulin reference substance. Conditions: mixture of acetonitrile and $0.1 \%$ TFA aqueous solution $(60: 40, \mathrm{v} / \mathrm{v})$ as mobile phase, flow rate at $1.0 \mathrm{~mL} / \mathrm{min}$, column temperature $25 \pm 1{ }^{\circ} \mathrm{C}, \mathrm{RP} \mathrm{C} 18$ - Luna ${ }^{\circledR}$ Phenomenex $(4.6 \times 250 \mathrm{~mm}, 5 \mu \mathrm{m}$ particle size $)$ column, UV detection wavelength at 214 with $20 \mu \mathrm{L}$ of injection volume. 
Table 2. Analysis of variance (ANOVA) for linearity

\begin{tabular}{cccccc}
\hline Source of variation & DF & SS & MS & F calculated & F critical \\
\hline Between groups & 6 & 71158775 & 11859796 & 2.80 & 2.96 \\
Within groups & 14 & 2222 & 159 & & \\
Total & 20 & 71160997 & & & \\
\hline
\end{tabular}

DF-degrees of freedom; SS-Sum of squares; MS-Mean square

The linearity of the method was assessed by plotting peak area against seven concentrations. For each concentration, three injections were performed and the average results of the chromatographic peak areas obtained were used for the study of linear regression using the leastsquares method. ${ }^{13-15}$ The analytical curve of insulin based on three calibration curves was shown to be linear over the proposed range $(0.5-100 \mu \mathrm{g} / \mathrm{mL})$ resulting in linear regression $\mathrm{y}=55.01775 \mathrm{x}+36.56067$, with $\mathrm{r}^{2}=0.9993$, as advised ${ }^{23}$ and shown in Figure 2. The statistical analysis was evaluated by ANOVA (Table 2) and data no presented significant linearity deviation at a $5 \%$ level of variance, exhibiting $\mathrm{F}$ calculated (2.80) lower than the F critical (2.96) demonstrating that the method used is linear in the range of 0.5 to $100 \mu \mathrm{g} / \mathrm{mL}^{24}$

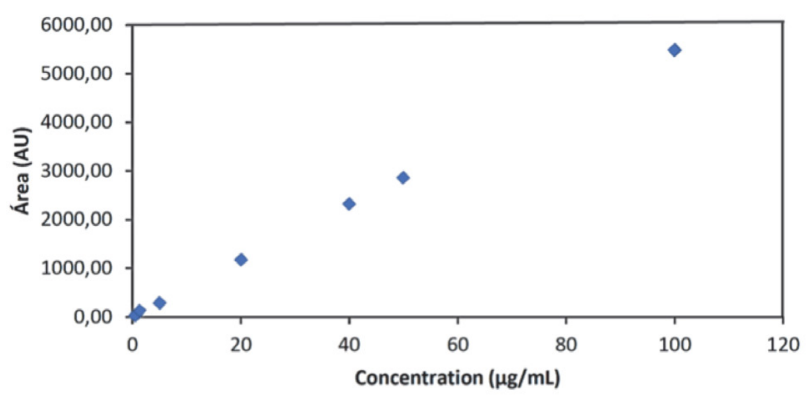

Figure 2. Calibration curve obtained with insulin standard solutions at seven concentration levels in the range of 0.5 to $100 \mu \mathrm{g} / \mathrm{mL}$ $(\mathrm{n}=21)$.

The precision was evaluated by calculating of relative standard deviation (RSD) of the samples, submitted to the repeatability (intra-day) and intermediate precision (inter-day). According to Table 3, the precision values were less than $5 \%$ as recommended, ${ }^{15}$ where $0.77 \%$ was found for repeatability and $1.18 \%$ was found for intermediate
Table 3. Results of intra and inter-day precision for determination of insulin in standard solutions.

\begin{tabular}{ccc}
\hline Level & Concentration $\boldsymbol{\mu g} / \mathbf{m L}$ & RSD $^{\mathbf{a}}(\%)$ \\
\hline $\begin{array}{l}\text { Repeatability (intra-day) } \\
\text { Intermediated precision } \\
\text { (inter-day) }\end{array}$ & $50 \mu \mathrm{g} / \mathrm{mL}$ & $0.77(\mathrm{n}=6)$ \\
\hline
\end{tabular}

${ }^{a} \mathrm{RSD}$ : relative standard deviation.

precision. These results indicate that the analytical method presented has good precision.

The accuracy of the method was determined by recovery studies, where the method of standard addition was used at three different levels $(5,20$ and $50 \mu \mathrm{g} / \mathrm{mL})$. The results are shown in Table 4 and the average recoveries for insulin were $97.58 \%$ within the range of $80-120 \%$ with an RSD of $1.27 \%$, evidencing the method is appropriate in quantify concentrations of insulin in liposome with accuracy.

The LOD and LOQ are used to measure the sensitivity of the method. DL represents the smallest amount of drug present in the sample that can be detected, but not necessarily quantified while QL represents the smallest amount of drug in the sample that can be measured with precision and accuracy by the method developed. ${ }^{13-15}$ The calculated LOQ and LOQ values were $0.097 \mu \mathrm{g} / \mathrm{mL}$ and $0.294 \mu \mathrm{g} / \mathrm{mL}$, respectively, demonstrating that the proposed method is adequate and safe for the quantification and detection of low insulin concentrations.

Robustness is a parameter typically performed in the development of the analytical method that indicates its ability to withstand small and deliberate variations in analytical conditions. ${ }^{15}$ It was evaluated by small modifications in four pre-established parameters, such as flow rate of the mobile phase, ratio of mobile phase, column tem-

Table 4. Determination of the recovery of the analytical method for insulin in liposomes

\begin{tabular}{cccccc}
\hline $\begin{array}{c}\text { Insulin standard } \\
\text { solution added } \\
(\boldsymbol{\mu g} / \mathbf{m L})\end{array}$ & $\begin{array}{c}\text { Insulin standard } \\
\text { solution found } \\
(\boldsymbol{\mu g} / \mathbf{m L})\end{array}$ & $\begin{array}{c}\text { Recovery } \\
(\%)\end{array}$ & $\begin{array}{c}\text { RSD }^{\mathbf{b}} \\
\mathbf{( \% )}\end{array}$ & $\begin{array}{c}\text { Average } \\
\text { Recovery (\%) }\end{array}$ \\
\hline $\mathrm{R} 1$ & 5 & 4.88 & 93.88 & 2.26 & 97.58 \\
$\mathrm{R} 2$ & 20 & 19.85 & 99.26 & 0.27 & \\
$\mathrm{R} 3$ & 50 & 49.74 & 99.61 & 1.28 & \\
\hline
\end{tabular}

${ }^{a}$ Mean of three replicates analysis. ${ }^{b}$ RSD: relative standard deviation. 
Table 5. Robustness of the analytical method for insulin quantification

\begin{tabular}{ccc}
\hline Chromathografic conditions & Recovery(\%) & RSD $^{\text {a }} \mathbf{( \% )}$ \\
\hline Flow rate of the mobile phase & & \\
$0.9 \mathrm{~mL} / \mathrm{min}$ & 98.8 & 0.60 \\
$1.1 \mathrm{~mL} / \mathrm{min}$ & 104.4 & 0.18 \\
Ratio of mobile phase & & \\
$61: 39$ & 99.3 & 0.05 \\
$59: 41$ & 98.0 & 0.20 \\
Column temperature $\left({ }^{\circ} \mathrm{C}\right)$ & & \\
$24^{\circ} \mathrm{C}$ & 101.3 & 0.58 \\
$26^{\circ} \mathrm{C}$ & 99.2 & 0.49 \\
Wavelength (nm) & & \\
$213 \mathrm{~nm}$ & 100.8 & 0.83 \\
$215 \mathrm{~nm}$ & 100.3 & 0.34 \\
\hline
\end{tabular}

${ }^{\mathrm{a}} \mathrm{RSD}$ : relative standard deviation.

perature and wavelength $(\mathrm{nm})$, using a concentration of 50 $\mu \mathrm{g} / \mathrm{mL}$. According to Table 5 , it was possible to verify that the method is robust since even with the variations made in the analytical conditions, the recovery results are within a previously specified range of $80-120 \%$ and RSD values showed less than $2 \%$.

\section{2. Application of the Validated Method}

Liposomes constituting important systems for the encapsulation, transport and sustained release of drugs, because their morphology is similar to that cellular membranes, besides protecting the drug against degradation. ${ }^{25-27}$ The validated method was used for the determination of insulin in liposomes composed by soybean phosphatidylcholine and cholesterol prepared by the thin film-hydration technique, through the encapsulation efficiency assay and the in vitro release profile of insulin from the liposomes. The encapsulation efficiency of insulin from liposome was found to be $67.19 \% \pm 2.4(\mathrm{SD}, \mathrm{n}=3)$, which shows a result superior to that found in similar papers. ${ }^{6,7,28}$ However, as far as we know, no study reported in the literature has addressed the encapsulation efficiency of insulin from liposomes using Amicon ultrafiltration filter extraction with consequent HPLC quantification. A study by Wallace and colleagues showed that ultrafiltration has several advantages over ultracentrifugation, such as rapid separation with low centrifugal forces, suggesting less potential for particle deformation and therefore less impairment of particle integrity. ${ }^{29}$ Figure 3 shows the release profiles of insulin in solution (PBS, pH 7.4) and insulin from the liposome. Both profiles have a biphasic release behavior, that is, it was observed an initial burst effect (fast release) in the first 2 hours, followed slower and sustained release delivery of insulin in the next hours. However, comparing the two release profiles it is noted that the release of insulin from the liposome was slower and sustained, suggest it is originated from the drug encapsulated in the aqueous liposome compartment and due to the process of diffusion of insulin through the bilayers. Pardakhty and collaborators obtained similar results in their studies as well as Zhang and collaborators. ${ }^{30,31}$

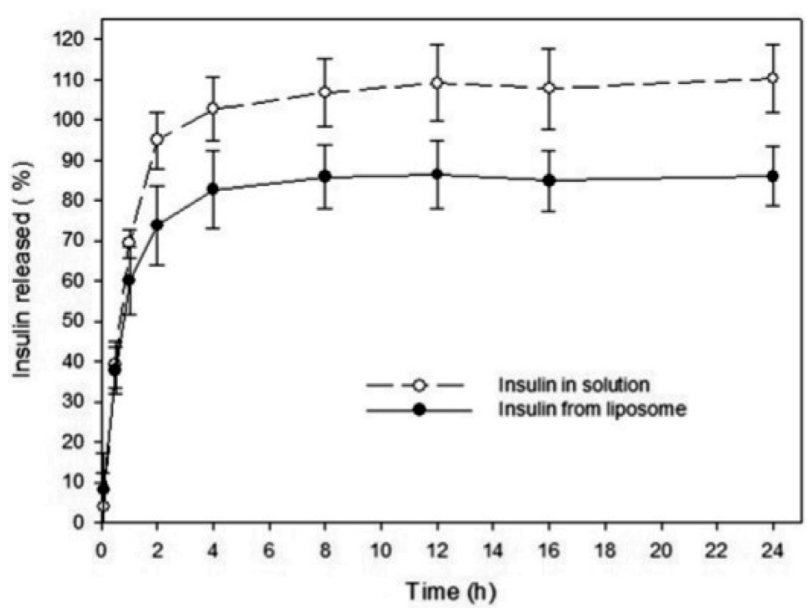

Figure 3. Release profiles of insulin in solution (open circles) and insulin from the liposome (solid circles). Each value express mean \pm standard deviation, $\mathrm{n}=5$.

\section{Conclusion}

The RP-HPLC method was developed and validated according to recognized guidelines (FDA, ICH and Anvisa) for the measurement of insulin in liposomes composed by soybean phosphatidylcholine and cholesterol and prepared using the hydration technique. The insulin encapsulation efficiency assay in liposomes and the in vitro release study using Franz diffusion cells were evaluated. The results indicated that the analytical method was linear, selective, precise, accurate and robust with low detection and quantification limits in a range from 0.5 to $100 \mu \mathrm{g} / \mathrm{mL}$ and are within the limits proposed by those guidelines. The method is simple, rapid and sensitive and may be used to determine insulin in liposomes in a short analysis time (about 4.5 minutes), which shows an advantage of the proposed method over those described in the literature. The suggested method can be used to analyze the encapsulation efficiency with adequate reliability. Regarding release profile of insulin from liposomes the data demonstrated a biphasic release behavior characterized by burst effect followed slower and sustained release.

\section{Acknowledgements}

The authors gratefully thank to FAPESP (São Paulo, Brazil), PADC-FCFar-UNESP (Araraquara, Brazil) and FUNDUNESP (São Paulo, Brazil) for financial support. This study was financed in part by the Coordenação de Aperfeiçoamento de Pessoal de Nível Superior - Brasil (CAPES) - Finance Code 001. 


\section{Conflict of Interest}

There are no conflicts to declare.

\section{References}

1. L. L. Brunton and B. C. Knollmann, As Bases Farmacológicas da Terapêutica de Goodman e Gilman, 13th ed. AMGH Editora. 2018.

2. S. Genuth, Type 1 diabetes mellitus. ACP Medicine. 2008, $1-19$.

3. B. G. Katzung and A. J. Trevor, Farmacologia Básica e Clínica, 13th ed. AMGH Editora. 2017.

4. C. Zylberberg and S. Matosevic. Drug Delivery. 2016, 23, 3319-3329. DOI:10.1080/10717544.2016.1177136

5. W. Zheng-Hong, P. Qi-neng, W. Yi and L. Jia-ming, Acta Pharmacol Sin. 2004, 25, 966-972.

6. N. Zhang, Q. N. Ping, G. H. Huang and W. F. Xu, Int. J. Pharm. 2005, 294, 247-259. DOI:10.1016/j.ijpharm.2005.01.018

7. M. Niu, Y. Lu, L. Hovgaard and W. Wu, Int. J. Nanomedicine. 2011, 6, 1155-1166.

8. P. Moslemi, A. R. Najafabadi and H. Tajerzadeh, Journal of Pharmaceutical and Biomedical Analysis. 2003, 33, 45-51. DOI:10.1016/S0731-7085(03)00336-4

9. B. Sarmento, A. Ribeiro, F. Veiga and D. Ferreira, Biomedical Chromatography. 2006, 20, 898-903.

DOI:10.1002/bmc.616

10. E. Déat-Lainé, V. Hoffart, J. M. Cardot, M. Subirade and E. Beyssac, Journal of Pharmaceutics. 2012, 439, 136-144. DOI:10.1016/j.ijpharm.2012.10.003

11. K. B. Chalasani, G. J. Russell-Jones, A. K. Jain, P. V. Diwan and S. K. Jain, Journal of Controlled Release. 2007, 122, 141-150. DOI:10.1016/j.jconrel.2007.05.019

12. E. Déat-Lainé., V. Hoffart, G. Garrait and E. Beyssac, International Journal of Pharmaceutics. 2013, 453, 336-342.

DOI:10.1016/j.ijpharm.2013.06.016

13. ICH, Q2 (R1); Validation of analytical procedures: text and methodology, International Conference on Harmonization. Geneva. 2005, pp.11-12.

14. FDA - Food and Drug Administration. Validation of Chromatographic Methods. Washington: Center for Drug and Evaluation and Research (CDER), Washington. 1994.

15. Brazil, Guide for validation of analytical and bioanalytical methods. Resolution RDC 166 of Brazilian National Health Surveillance Agency (ANVISA), 2017.
16. A. D. Bangham, M. M. Standish and J. C. Watkins, J. Mol. Biol. 1965, 13, 238-252. DOI:10.1016/S0022-2836(65)80093-6

17. K. M. Hosny, AAPS PharmSciTech. 2010, 11, 241-246. DOI:10.1208/s12249-009-9373-4

18. Z. Degim, N. Ünal, D. Eşsiz and U. Abbasoglu, Life Sciences. 2004, 75, 2819-2827. DOI:10.1016/j.lfs.2004.05.027

19. X. Xu, M. A. Khan and D. J. Burgess, International Journal of Pharmaceutics. 2012, 423, 410-418.

DOI:10.1016/j.ijpharm.2011.12.019

20. J. Lindemann, R. Leiacker, G. Rettinger, and T. Keck, Clinical Otolaryngology \& Allied Sciences. 2002, 27, 135-139.

DOI:10.1046/j.1365-2273.2002.00544.x

21. T. Keck, R. Leiacker, H. Riechelmann and G. Rettinger, The Laryngoscope. 2000, 110, 651-654.

DOI:10.1097/00005537-200004000-00021

22. FDA. Food and Drug Administration - Analytical Procedures and Methods Validation for Drugs and Biologics. Guidance for Industry. 2015, pp. 1-15.

23. N. A. Épshtein, Pharmaceutical Chemistry Journal. 2004, 38, 212-228. DOI:10.1023/B:PHAC.0000038422.27193.6c

24. I. C. Pinto, C. Cerqueira-Coutinho, Z. M. F.D. Freitas, E. P, D. Santos, F. A. D. Carmo and E. R. Junior, Brazilian Journal of Pharmaceutical Sciences. 2017, 53, 1-8. DOI:10.1590/s2175-97902017000216033

25. N. C. Santos and M.A.R.B. Castanho, Química Nova. 2002, 25, 1181-1185. DOI:10.1590/S0100-40422002000700019

26. G. Bozzuto and A. Molinari, International Journal of Nanomedicine. 2015, 10, 975-999. DOI:10.2147/IJN.S68861

27. J. O. Eloy, M. C. D. Souza, R. Petrilli, J. P. A. Barcellos, R. J. Lee and, J. M. Marchetti, Colloids and surfaces B: Biointerfaces. 2014, 123, 345-363. DOI:10.1016/j.colsurfb.2014.09.029

28. S. J. Park, S. G. Choi, E. Dava and J. S. Park, International Journal of Pharmaceutics. 2011, 415, 267-272.

DOI:10.1016/j.ijpharm.2011.05.061

29. S. J. Wallace, J. Li, R. L, Nation. \& B. J. Boyd, Drug Delivery and Translational Research. 2012, 2, 284-292.

DOI:10.1007/s13346-012-0064-4

30. A. Pardakhty, J. Varshosaz and A. Rouholamini, International Journal of Pharmaceutics. 2007, 328, 130-141.

DOI:10.1016/j.ijpharm.2006.08.002

31. X. Zhang, X. Zheng, Z. Wu, X. Gao, S. Shu, Z. Wang and C. Li, Carbohydrate Polymers. 2011, 84, 1419-1425.

DOI:10.1016/j.carbpol.2011.01.057 


\section{Povzetek}

Inzulin je pomemben anabolični hormon, ki uravnava presnovo ogljikovih hidratov, lipidov in beljakovin. $\mathrm{V}$ tej raziskavi je bila metoda reverzno fazne tekočinske kromatografije (RP-LC) uspešno validirana in preizkušena na učinkovitost enkapsulacije inzulina in in vitro študij sproščanja. HPLC analize smo izvedli s kolono RP C18-Luna ${ }^{\circledR}$ Phenomenex $(4,6$ $\times 250 \mathrm{~mm}$, velikost delcev $5 \mu \mathrm{m}$ ), pri sobni temperaturi, $\mathrm{z}$ uporabo mobilne faze sestavljene iz mešanice acetonitrila in $0,1 \%$ vodne raztopine TFA $(60: 40, \mathrm{v} / \mathrm{v})$, v izokratskem načinu s pretokom $1,0 \mathrm{~mL} / \mathrm{min}, \mathrm{z}$ ultravijolično detekcijo pri 214 $\mathrm{nm}$, volumen injicirane raztopine pa je znašal $20 \mu \mathrm{L}$. Validacija metode je bila izvedena v skladu s priznanimi smernicami glede ustreznosti sistema, specifičnosti, linearnosti, natančnosti, točnosti, meje detekcije (LOD), meje kvantizacije (LOQ) in robustnosti. Pokazalo se je, da je metoda linearna v območju od 0,5-100 $\mu \mathrm{g} / \mathrm{mL}\left(\mathrm{r}^{2}=0,9993\right)$ selektivna, natančna, robustna, točna $\mathrm{z}$ vrednostmi LOD in LOQ, $0,07 \mu \mathrm{g} / \mathrm{mL}$ oziroma $0,294 \mu \mathrm{g} / \mathrm{mL}$. Razvita metoda se je izkazala za ustrezno za analizo učinkovitosti enkapsulacije in analizo profila sproščanja inzulina iz liposomov. 